\title{
Anak Berhadapan Hukum Ditinjau Dari Aspek Psikologi Hukum
}

\author{
Widya Romasindah Aidy \\ Fakultas Hukum, Universitas Bhayangkara Jakarta Raya \\ Email: widya.romasindah@dsn.ubharajaya.ac.id
}

Received : 24 Nop 2021 | Revised : 3 Dec 2021 | Accepted : 5 Dec 2021 | Published : 9 Dec 2021

\begin{abstract}
Children as a mandate as well as the gift of God Almighty, we must always guard because in him the inherent dignity, dignity and rights as human beings must be upheld and basically, the occurrence of juvenile delinquency shows that there is an indiscipline of adolescents to the rules and norms that apply, both the family, school, community and self-norms as individuals, and the planting of these norms must certainly be given to adolescent individuals so that they have a good understanding of these norms. The purpose of this study is expected to be able to understand children who are dealing with the law in terms of legal psychology. The method used in this study is a normative juridical research method and analyzed data qualitatively by means of literature study, namely studying, understanding, identifying and recording literature, legislation and data relating to research problems so that it can be concluded that in dealing with children facing the law there is a need for a psychological approach in the law that refers to the application of specific legal psychology in the law in analyzing the causes of violations committed by children and the cause of lawbreakers who are still children or juvenile offenders.
\end{abstract}

Keywords: Children, Juvenile Delinquency, Psychology in Law

\begin{abstract}
ABSTRAK
Anak sebagai amanah sekaligus karunia Tuhan Yang Maha Esa, senantiasa harus kita jaga karena dalam dirinya melekat harkat, martabat dan hak-hak sebagai manusia yang harus dijunjung tinggi dan pada dasarnya, terjadinya kenakalan remaja menunjukkan adanya ketidakdisiplinan remaja terhadap aturan dan norma yang berlaku, baik itu keluarga, sekolah, masyarakat maupun norma diri sebagai individu, dan penanaman norma tersebut sebelumnya tentu harus diberikan kepada individu remaja agar mereka mempunyai pemahaman yang baik terkait dengan norma tersebut. Tujuan dari penelitian ini untuk dapat mengidentifikasi anak yang berhadapan hukum dari aspek psikologi hukum. Metode yang digunakan dalam penelitian ini adalah metode penelitian secara yuridis normatif dan dianalisis data secara kualitatif dengan cara studi kepustakaan, yaitu mempelajari, memahami, mengidentifikasi dan mencatat literatur, peraturan perundang-undangan serta data-data yang berhubungan dengan
\end{abstract}


masalah penelitian sehingga dapat disimpulkan bahwa dalam menangani anak yang berhadapan hukum perlu adanya pendekatan secara psikologi dalam hukum yaitu mengacu pada penerapan-penerapan spesifik psikologi hukum di dalam hukum dalam menganalisis sebab-sebab pelanggaran yang dilakukan oleh anak serta penyebab adanya pelanggar hukum yang masih anak-anak atau juvenile offenders.

Kata Kunci: Anak, Kenakalan Anak, Psikologi Dalam Hukum

\section{PENDAHULUAN}

Kehadiran anak dalam kehidupan keluarga sangat dinantikan. Belum lengkap ikatan perkawinan jika belum atau tidak dikarunia anak. Berbagai ikhtiar dilakukan oleh pasangan suami istri untuk mempunyai anak. Hal ini menggambarkan betapa penting dan berartinya anak bagi keluarga dan dalam skala besar juga untuk negara.

Mengingat anak mempunyai peran penting dalam kehidupan, maka permasalahan anak yang pada awalnya merupakan masalah pribadi yaitu masalah hubungan antara orang tua dengan anaknya, lambat-laun permasalahan anak diletakkan sebagai persoalan publik dimana Pemerintah harus hadir melalui berbagai instrumen regulasinya untuk mengatur semua kepentingan hukum terhadap anak sekaligus juga untuk menjamin keberlangsungan anak secara baik dan berguna. Peran pemerintah melalui regulasi ini mengingat anak merupakan kelompok yang rawan dan rentan dieksploitasi karena secara fisik maupun mental anak tetapi tidak sedikit juga telah berhadapan dengan hukum $(\mathrm{ABH})$.

Perkembangan anak memang tidak terlepas dari perkembangan lingkungan tempat dimana ia berada. Lingkungan yang dimaksud tidak hanya keluarga inti, tetapi juga saudara, sekolah, tetangga maupun teman-teman. Koji Yamashita, sebagaimana yang dikutip oleh Apong Herlina (2004:182) menyatakan:

"Anak belajar dari cara mereka dibesarkan. Kalau mereka dibesarkan dengan kritikan maka mereka akan belajar untuk mencari kesalahan orang lain, kalau mereka dibesarkan dengan permusuhan, maka mereka akan belajar berkelahi. Jika mereka dibesarkan dengan toleransi, maka mereka akan belajar untuk bersabar, kalau mereka dibesarkan dengan perlakuan adil maka mereka akan belajar untuk menghargai."

Pernyataan di atas menunjukkan bahwa lingkungan yang positif akan memberikan perkembangan kejiwaan atau mental yang baik pada si anak, sedangkan lingkungan yang negatif membuat si anak mudah meniru dan terpengaruh oleh perbuatan-perbuatan yang menyimpang dari lingkungannya, walaupun bukan berarti anak yang dibesarkan dalam lingkungan yang positif tidak akan menjadi penjahat, namun diakui bahwa peniruan dalam masyarakat.

Menurut Komite Nasional Perlindungan Anak, kasus kekerasan dan kejahatan yang dialami oleh anak bisa dilakukan oleh siapa saja, baik orang tua mereka sendiri, pemerintah, maupun oleh sesama teman sebaya. Berbagai akibat kekerasan yang dialami oleh anak, baik anak sebagai victims (korban) maupun sebagai pelaku sangat berpengaruh terhadap kondisi psikologis anak. Gangguan-gangguan psikologis biasanya meliputi trauma, luka batin, kecemasan, perasaan curiga, depresi, frustrasi, 
penyesalan yang sangat mendalam, dendam, pemarah, kehilangan kepercayaan kepada masyarakat, dan kehilangan kepercayaan diri.

Anak yang melakukan pelanggaran hukum atau tindakan kejahatan, tidak bisa sepenuhnya dipersalahkan, karena faktor lingkungan juga mempengaruhi sikap, perilaku dan tindakan anak. Bila dilihat dari kondisi anak-anak tersebut, sebenarnya mereka adalah korban dari lingkungan. Maka dari itu, anak-anak tersebut lebih tepat disebut dengan istilah anak-anak yang berhadapan dengan hukum, bukannya anakanak pelaku kriminal. Berkaitan dengan permasalahan tersebut, kita tidak bisa menampik dilema yang berkembang di masyarakat mengenai anak yang berkonflik dengan hukum. Di satu sisi masyarakat harus memandang bahwa anak-anak adalah korban dari lingkungannya, di satu sisi lain perilaku mereka sudah semakin merugikan dan tidak bisa ditolerir lagi.

$\mathrm{ABH}$ harus dilihat secara komprehensif baik sosiologis, psikologis dan juridis formalnya. Jika dilakukan secara cermat maka akan kita dapatkan upaya perlindungan menyeluruh terhadap hak anak dan hak asasi manusia. Dan kita semua berharap di era perubahan ini merupakan saat yang tepat untuk membangun segala sesuatu secara lebih baik diberbagai bidang, baik hukum, sosial, dan politis. Berbagai instansi telah melakukan berbagai orientasi, posisi dan penciptaan paradigma baru dalam melakukan pelayanan terhadap rakyat. Akhirnya kita berharap dukungan berbagai pihak yang terlibat didalam program ini akan dapat berperan secara aktif demi kepentingan terbaik bagi anak.

\section{Landasan Teori}

Pada tahap perkembangan sosial emosi anak, Erickson menjelaskan bahwa pada usia 9-10 tahun anak berada pada fase industry dan inferiority (tekun versus perasaan rendah diri). Pada fase ini, anak mengalami perkembangan dalam berpikir deduktif, disiplin diri, kemampuan berhubungan dengan teman sebaya, dan rasa ingin tahu yang mendalam. Anak mampu mempelajari hubungan kausalitas yang akan dikerjakannya, mampu memperhatikan apa yang akan terjadi di sekitarnya, dan kemampuan dalam berimajinasi. (Santrock, J.W., \& Yussen, S.R., 1992 : 15)

Kenakalan remaja (juvenile delinquency) adalah perilaku yang mencerminkan adanya kesalahan dalam pola pendidikan, baik itu pendidikan di rumah dan masyarakat maupun di sekolah. Tentu saja hal ini tidak bisa dinilai dari satu aspek, tapi harus melibatkan banyak aspek, termasuk aspek individu remaja itu sendiri. Pada dasarnya, terjadinya kenakalan remaja menunjukkan adanya ketidakdisiplinan remaja terhadap aturan dan norma yang berlaku, baik itu keluarga, sekolah, masyarakat maupun norma diri sebagai individu, dan penanaman norma tersebut sebelumnya tentu harus diberikan kepada individu remaja agar mereka mempunyai pemahaman yang baik terkait dengan norma tersebut.

Penyebab yang mempengaruhi tindakan kriminal pada anak menurut Meilala dan Sumaryono, yaitu faktor lingkungan, ekonomi, sosial, dan psikologis. Anak-anak yang berada di bawah usia 7 tahun dianggap tidak memiliki keinginan untuk melakukan tindakan kriminal (incapable of having the criminal intens), sedangkan anak-anak yang berada di kisaran usia 7 sampai 14 tahun pada umumnya memiliki keinginan untuk melakukan tindakan kriminal, berarti anak tidak mampu melakukan kriminalitas (incapable of crime) sedangkan menurut pandangan psikogenis terhadap anak-anak yang berhadapan dengan hukum itu disebabkan oleh faktor intelejensi, kepribadian, motivasi, sikap-sikap yang salah dan kecenderungan psikopatologi. Pada 
umumnya anak-anak yang berhadapan hukum melakukan banyak tindak kejahatan di dorong oleh konflik batinnya dimana memiliki tingkah yang agresif, impulsif dan primitif.

Menurut Kartono (2014:45) bahwa anak-anak yang delinkuensi mempraktikkan konflik batin mereka untuk mengurangi beban tekanan jiwa sendiri melalui tingkah laku agresif, impulsif, dan primitif. Oleh karena itu, tindakan kriminal anak-anak pada umumnya berkaitan erat dengan temperamen, konstitusi kejiwaan yang chaos, konflik batin, dan frustrasi yang akhirnya ditampilkan secara spontan dalam bentuk kriminalitas.

Melalui penelitian ini bertujuan untuk mengidentifikasi anak yang berhadapan dengan hukum. Hasil penelitian ini diharapkan dapat bermanfaat sebagai masukan bagi bahan kajian, sumbangan pemikiran dan dalam hal perkembangan hukum atau ilmu hukum pada umumnya dan dapat memberikan informasi mengenai anak berhadapan hukum ditinjau dari aspek psikologi hukum. Untuk itu, dalam penelitian ini diharapkan dapat (1) mengetahui permasalahan yang dialami anak-anak yang berhadapan dengan hukum, (2) mengetahui peranan psikologi hukum terhadap $\mathrm{ABH}$.

\section{METODE PENELITIAN}

Dalam menangani ABH diharapkan diperoleh data yang dapat memberikan gambaran tentang permasalahan-permasalahan yang dihadapi anak nakal secara psikologi dan kebutuhan-kebutuhan apa yang diperlukan anak dalam memenuhi hak anak. Jenis penelitian yang dilakukan adalah penelitian kualitatif dan penelitian yuridis normatif. Karakteristik penelitian ini adalah bersifat deskriptif serta dalam pengumpulan data digunakan dengan cara studi kepustakaan, yaitu mempelajari, memahami, mengidentifikasi dan mencatat literatur, peraturan perundang-undangan serta datadata yang berhubungan dengan masalah penelitian.

Data yang diperoleh selanjutnya disajikan dalam bentuk uraian yang bersifat deskriptif sistematis, logis, dan rasional. Dalam arti keseluruhan data yang diperoleh akan dihubungkan satu dengan yang lainnya dan disesuaikan dengan pokok permasalahan sehingga merupakan satu kesatuan yang utuh dengan pokok permasalahan yang diteliti. Data tersebut, selanjutnya dianalisis secara kualitatif, artinya data ditafsirkan dan didiskusikan berdasarkan teori-teori (doktrin) dan asasasas serta peraturan hukum yang berkaitan dengan pokok permasalahan.

\section{PEMBAHASAN}

\section{Anak Berhadapan Hukum}

Dalam Pasal 45 KUHP, anak adalah orang yang belum cukup umur, dengan belum cukup umur dimaksud adalah mereka yang melakukan perbuatan sebelum umur 16 tahun. Pada Pasal 47 ayat (1) menyatakan bahwa anak yang belum mencapai umur 18 tahun atau belum pernah melakukan pernikahan, ada di bawah kekuasaan orangtuanya selama mereka tidak dicabut kekuasaan orangtuanya. Sedangkan Pasal 91 ayat (4) KUHP mengatakan: "Dengan anak, dimaksud pula orang ada di bawah kekuasaan yang sama dengan Kekuasaan Bapak". 
Menurut Pasal 1 ayat (1) Undang-Undang Nomor 35 Tahun 2014 tentang Perubahan Atas Undang-Undang Nomor 23 Tahun 2002 tentang Perlindungan Anak, anak adalah seseorang yang belum berusia 18 tahun, termasuk anak yang masih dalam kandungan. Kemudian pada Pasal 1 ayat (3) dan Pasal 20 Undang-Undang Nomor 11 Tahun 2012 tentang Sistem Peradilan Pidana, dirumuskan: 1). Batas umur anak yang berhadapan hukum dapat diajukan ke Sidang Pengadilan Anak adalah sekurangkurangnya 12 (dua belas tahun) tahun tetapi belum mencapai umur 18 tahun dan belum pemah kawin, dan 2). Dalam hal anak melakukan tindak pidana pada batas umur sebagaimana dimaksud dalam Pasal 20 bahwa Anak yang berhadapan hukum sebelum genap berumur 18 (delapan belas) tahun dan diajukan ke sidang pengadilan setelah anak tersebut telah melampaui batas umur 18 (delapan belas) tahun, tetapi belum mencapai umur 21 (dua puluh satu) tahun, anak tetap diajukan ke sidang anak.

Ditinjau dari segi sosiologi, batasan umur seseorang disebut anak menurut Dellyana adalah: "Mereka yang belum dewasa dan yang menjadi dewasa karena peraturan tertentu (mental, fisik masih belum dewasa). Selain itu anak disini meliputi anak sebagai pelaku korban dan pengamat/ saksi. Masing-masing mempunyai hak untuk tidak menjadi korban dalam proses peradilan pidana tertentu".

Arti Delinkuen berasal dari delinquency, yang diartikan dengan kenakalan anak, kenakalan remaja, kenakalan pemuda dan delikuensi. Kata Delinkuensi atau Delinquency erat kaitannya dengan anak, sedangkan kata delinquent act bisa diartikan sebagai perbuatan yang melanggar norma dasar dari masyarakat. Perbuatan tersebut apabila dilakukan oleh kelompok anak-anak, maka disebut delinquency. Jadi delinquency mengarah pada pelanggaran terhadap aturan yang dibuat kelompok sosial masyarakat tertentu bukan hanya hukum Negara saja.

Menurut Sudarsono (Maidin Gultom, 2008:56), suatu perbuatan dikatakan delinkuen apabila perbuatan-perbuatan tersebut bertentangan dengan norma yang ada dalam masyarakat dimana ia hidup atau suatu perbuatan yang anti sosial yang didalamnya terkandung unsur-unsur anti normatif.

Penyebab kenakalan anak disebabkan oleh beberapa faktor, antara lain:

1. Teori biologis dan biososial, menurut kedua teori tersebut kenakalan anak disebabkan oleh samatotype, warisan, pengaruh kebiasaan (conditionability and delinquency)

2. Teori social disorganization, teori psikologi, dan anomie menyatakan kenakalan anak adalah disebabkan oleh faktor lingkungan di mana seseorang itu berada, teori lower class, dan teori differential culture (teori penyimpangan kebudayaan)

Menurut Heally dan Bronner (Marlina, 2009:69), 91\% dari perilaku kriminal anak disebabkan karena tidak bahagia dan memiliki gangguan emosional. Dalam hal ciri-ciri pribadi pelaku digambarkan sebagai pencemburu, merasa kurang dalam hal pribadi, dan selalu merasa dipersalahkan.

Istilah "anak yang berhadapan dengan hukum" membuat anak benar-benar berhadapan dengan hukum yang menyebabkan anak akan alergi dengan hukum. Padahal dalam pandangan seorang anak, hukum diasosiasikan seperti menaruh sepatu pada tempatnya, menutup kembali pintu kamarnya, membereskan buku-buku pelajaran dan sebagainya. Adanya konvensi hak anak yang berisi peraturan-peraturan internasional yang diadaptasi ke dalam hukum nasional dalam bentuk Undang-Undang seringkali menakutkan bila ditinjau dari sudut pandang "berlindung dibalik hukum". Masalah klasik yang dihadapi oleh kita adalah cenderung mengagung-agungkan 
HAM, konvensi, dan intervensi. (Anwar Y, 2009:70)

Proses intervensi tindakan kriminal anak berkaitan erat dengan kebijakan kriminal (criminal policy). Menurut Suharto (Budiarto, S., 2013:42), kebijakan kriminal merupakan salah satu cara untuk menanggulangi kejahatan, di dalam prosesnya mengacu pada dua jalur, yaitu kebijakan penal dan kebijakan non-penal. Selain itu, hukum pidana cenderung merugikan masa depan anak karena meninggalkan stigma negatif pada anak. Seorang anak terpaksa harus berhadapan dengan proses hukum yang panjang, mulai dari proses penyidikan oleh kepolisian, penuntutan oleh jaksa, proses persidangan di pengadilan, dan proses penahanan di rumah tahanan. Kondisi tersebut dapat memberikan tekanan baik fisik maupun mental bagi anak yang berhadapan dengan hukum.

Anak yang berhadapan hukum $(\mathrm{ABH})$ merupakan anak yang berkonflik dengan hukum dan anak korban tindak pidana. Anak yang melakukan tindakan melawan hukum merupakan salah satu bentuk perilaku menyimpang. Akibat dari tindak perilaku menyimpang oleh $\mathrm{ABH}$ pada akhirnya membuat anak tersebut harus merasakan sanksi pidana sebagai akibat perbuatannya.

\section{Permasalahan Yang Dialami Anak-Anak Yang Berhadapan Dengan Hukum} Menurut Komisi Perlindungan Anak Indonesia (KPAI) kasus pelanggaran hak anak pada 2018 mencapai 4.885 kasus dan jumlah ini meningkat sebanyak 306 dari tahun 2017 sebanyak 4.579 kasus dan kasus anak berhadapan dengan hukum yang merupakan urutan pertama dengan jumlah sebanyak 1.434 kasus. (Devina Halim, 2019)

Ditinjau dari latar belakang $\mathrm{ABH}$, pada umumnya, $\mathrm{ABH}$ berjenis kelamin lakilaki dan berusia antara 13 hingga 17 tahun. Status pendidikan dan ekonomi ABH pun tergolong sangat rendah. Pendidikan ABH pada umumnya yaitu lulusan SMP atau bahkan ada yang tidak lulus SD, sedangkan kondisi sosial ekonomi pun kalangan menengah ke bawah.

Ada motivasi intrinsik dan ekstrinsik yang bisa dipelajari untuk menganalisis kejahatan yang dilakukan anak atau kenakalan anak dan remaja. Yang termasuk motivasi intrinsik adalah faktor intelegensi, usia, jenis kelamin, dan kedudukan anak dalam keluarga (Soetodjo \& Wagiati, 2006). Faktor intelegensi dapat memengaruhi anak dalam mempertimbangkan baik atau buruknya perilaku yang dilakukan, usia memengaruhi pola pikir dan pemahaman moral di masyarakat tempat tinggalnya, jenis kelamin laki-laki cenderung lebih rentan melakukan pelanggaran hukum, dan kedudukan anak dalam keluarga pun akan memengaruhi psikologis anak ketika melakukan kejahatan. Sedangkan yang termasuk motivasi ekstrinsik adalah faktor rumah tangga, pendidikan dan sekolah, pergaulan anak, dan media massa (Soetodjo \& Wagiati, 2006).

Faktor-faktor ini dapat menyebabkan anak yang awalnya berperilaku baik, ketika ada masalah dalam keluarganya, sekolah tidak menerapkan aturan yang tegas, pergaulan yang salah dan menyimpang dari norma masyarakat, serta pengaruh media massa yang menayangkan berbagai adegan buruk yang bisa dicontoh oleh anak, dapat melakukan tindak pidana sehingga terpaksa harus berurusan dengan hukum dan sistem peradilan. Anak yang telah melanggar hukum dan tertangkap polisi akan menjalani serangkaian proses pemeriksaan, penyidikan, dan sampai akhirnya dijebloskan ke penjara. Kehidupan di Lembaga Permasyarakatan di Indonesia sudah mulai banyak 
diteliti. Mulai dari praktisi hukum, lembaga bantuan hukum, orang yang bergerak di lembaga swadaya masyarakat, orang yang berada di lingkungan akademik, dan juga

Pemberian sanksi pidana terhadap anak yang berhadapan hukum perlu mempertimbangkan perlindungan dan kepentingan anak. Termasuk didalamnya adalah kesejahteraan anak yang tidak boleh diabaikan. Apabila kesejahteraan anak tidak diperhatikan maka akan merugikan anak itu sendiri terutama dalam mendapatkan hak-haknya. Hak-hak anak dalam proses peradilan dapat dipahami sebagai perwujudan dari keadilan. Dalam konteks ini, melalui pendekatan kesejahteraan dapat dijadikan sebagai landasan filosofi penanganan terhadap pelanggaran hukum yang dilakukan oleh anak. Pendekatan ini pada prinsipnya menekankan 2 (dua) aspek. Pertama, anak-anak dianggap belum benar-benar memiliki kesalahan yang telah dilakukannya, sehingga sudah sepantasnya diberikan pengurangan hukuman serta pembedaan pemberian hukuman bagi anak-anak dengan orang dewasa. Kedua, jika dibandingkan dengan orang dewasa, anak-anak diyakini lebih mudah dibina dan dididik daripada orang dewasa.

\section{Peranan Psikologi Hukum terhadap ABH}

Psikologi hukum menurut Soerjono Soekanto (Achmad Ali, 1990:188) adalah studi hukum yang akan berusaha menyoroti hukum sebagai salah satu perwujudan dari gejala-gejala kejiwaan tertentu, dan juga landasan kejiwaan dari perilaku atau sikap tindak tersebut.

Psikologi hukum merupakan bidang yang baru dalam kajian ilmu hukum. Letak psikologi hukum dalam kajian hukum yaitu ada dalam kajian empiris terhadap hukum. Pendekatan psikologi terhadap hukum dimaksudkan untuk mengkaji perilaku-perilaku masyarakat sebagai subjek hukum dalam melihat fenomena hukum yang ada. Pendekatan psikologi hukum menekankan determinan-determinan manusia dalam hukum, termasuk dari perundang-undangan dan putusan hakim.

Kaitan antara fungsi dan peranan psikologi dalam hukum, menurut Farrington dan Hawkins (Andi hamzah, 2009:35) bahwa peranan psikologi dalam hukum dapat dibagi menjadi 3 (tiga) jenis, yaitu: 1). psikologi dapat digunakan untuk menguji kebenaran pra-anggapan yang digunakan dalam hukum itu sendiri; 2). dapat digunakan dalam proses hukum; dan 3). digunakan dalam sistem hukum itu sendiri.

Menurut Blackburn (Andi Hamzah, 2009:80), ada beberapa pendekatan yang dilakukan terhadap psikologi hukum anatara lain: Psychology in Law, Psychology and Law, Psychology of Law, dan yang terakhir pendekatan secara Psychology in the courts of Forensic Psychology.

Tidak hanya itu perkembangan psikologi anak yang masih labil dan mudah terpengaruh menjadi faktor terjadinya tindak pidana yang dilakukan oleh anak sehingga dalam aspek psikologi hukum penulis menggunakan pendekatan secara psychology in law (Psikologi dalam Hukum) yaitu mengacu pada penerapanpenerapan spesifik psikologi hukum di dalam hukum, dalam menganalisis sebab-sebab pelanggaran yang dilakukan oleh anak serta penyebab adanya pelanggar hukum yang masih anak-anak atau juvenile offenders. Maka dapat dikatakan pengaruh lingkungan, kebiasaan, gaya hidup, pendidikan, dan ekonomi serta perkembangan teknologi yang secara tidak langsung mempengaruhi pembentukan perilaku anak yang cenderung mengarah ke perbuatan-perbuatan yang melanggar aturan yang berlaku sehingga terjaditindak pidana yang dilakukan oleh anak.

Pendekatan psikologi hukum memiliki peran dalam menerapkan spesifik psikologi di dalam hukum, dalam menganalisis sebab-sebab pelanggaran yang dilakukan oleh anak serta penyebab adanya pelanggar hukum yang masih anak-anak 
atau juvenile offenders. Perubahan pada pola perilaku, sikap dan kepribadian pada masa remaja merupakan faktor yang dianggap penting. Berdasarkan referensi tersebut perilaku remaja adalah perubahan yang positif dan negatif itu wajar adanya tetapi remaja harus mewaspadai pengaruh dari luar baik lingkungan dan pergaulan yang dapat membawa penyimpangan dan kebrutalan dalam kenakalan. Jika remaja tersebut terbawa oleh pengaruh-pengaruh itu yang tidak normal.

\section{KESIMPULAN}

Dari pembahasan di atas, bisa dinyatakan bahwa kenakalan anak itu memang ada kaitannya dengan anak yang berhadapan hukum. Anak yang berhadapan hukum $(\mathrm{ABH})$ merupakan anak yang berkonflik dengan hukum dan anak korban tindak pidana. Anak yang melakukan tindakan melawan hukum merupakan salah satu bentuk perilaku menyimpang. Akibat dari tindak perilaku menyimpang oleh $\mathrm{ABH}$ pada akhirnya membuat anak tersebut harus merasakan sanksi pidana sebagai akibat perbuatannya.

Pemberian sanksi pidana terhadap anak yang berhadapan hukum perlu mempertimbangkan perlindungan dan kepentingan anak. Termasuk didalamnya adalah kesejahteraan anak yang tidak boleh diabaikan. Apabila kesejahteraan anak tidak diperhatikan maka akan merugikan anak itu sendiri terutama dalam mendapatkan hak-haknya. Hak-hak anak dalam proses peradilan dapat dipahami sebagai perwujudan dari keadilan. Dalam konteks ini, melalui pendekatan kesejahteraan dapat dijadikan sebagai landasan filosofi penanganan terhadap pelanggaran hukum yang dilakukan oleh anak. Pendekatan ini pada prinsipnya menekankan 2 (dua) aspek. Pertama, anak-anak dianggap belum benar-benar memiliki kesalahan yang telah dilakukannya, sehingga sudah sepantasnya diberikan pengurangan hukuman serta pembedaan pemberian hukuman bagi anak-anak dengan orang dewasa. Kedua, jika dibandingkan dengan orang dewasa, anak-anak diyakini lebih mudah dibina dan dididik daripada orang dewasa dan perlu adanya pendekatan secara psychology in law (Psikologi dalam Hukum) yaitu mengacu pada penerapan-penerapan spesifik psikologi hukum di dalam hukum dalam menganalisis sebab-sebab pelanggaran yang dilakukan oleh anak serta penyebab adanya pelanggar hukum yang masih anak-anak atau juvenile offenders.

\section{DAFTAR PUSTAKA}

Ali, Achmad, Mengembara Di Belantara Hukum. Ujung Pandang. Makassar: Lembaga Penerbit Universitas Hasanuddin, 1990

, Buku Ajar Psikologi Hukum Fakultas Hukum Unhas, Makassar: Lembaga Penerbit Universitas Hasanuddin, 2009

Anwar, Y, Saat menuai kejahatan: Sebuah Pendekatan Sosiokultural, Kriminologi, Hukum, dan HAM. Bandung: Refika Aditama. 2009

Apong Herlina, Et. Al., Perlindungan Terhadap Anak Yang Berhadapan Dengan Hukum, Manual Pelatihan Untuk Polisi, Jakarta: UNICEF, 2004 
Budiarto, S, Dinamika Perkembangan Sosial Emosi Anak yang berhadapan dengan Hukum (ABH), Surabaya: Revka Petra Medika, 2013.

Gultom, Maidin, Perlindungan Hukum Terhadap Anak "Dalam Sistem Peradilan Pidana Anak Di Indonesia”, Bandung: PT Refika Aditama, 2008

Hamzah, Andi, Hukum Acara Pidana Indonesia, Jakarta: PT. Sinar Grafika Offset, 2005

Halim, Devina, Sepanjang 2018, KPAI Terima 4.885 Kasus Pelanggaran Hak Anak, https://nasional.kompas.com/read/2019/01/08/18472551/sepanjang-2018-kpaiterima-4885-kasus-pelanggaran-hak-anak

Kartono, K, Patologi Sosial 2: Kenakalan Remaja. Jakarta: PT Raja Grafindo Persada, 2014

Marlina, Peradilan Pidana Anak di Indonesia "Pengembangan Konsep Diversi dan Restorative Justice", Bandung: PT. Refika Aditama, 2009

Purnianti., Supatmi, M.S., \& Tinduk, M.M., Analisa Situasi Sistem Peradilan Pidana Anak (juvenile justice system) di Indonesia. UNICEF Indonesia, 2003

Republik Indonesia, Undang-Undang Nomor 11 Tahun 2012 tentang Sistem Peradilan Pidana Anak

, Undang-Undang Nomor 35 Tahun 2014 tentang Perubahan Atas Undang-Undang Nomor 23 Tahun 2002 tentang Perlindungan Anak

Santrock, J.W., \& Yussen, S.R., “Child Development”, 5 th Ed. Dubuque, IA, 1992

Soetodjo \& Wagiati, Hukum Pidana Anak. Bandung: PT Refika Aditama, 2006 